\title{
Detection of Immunoglobulin Y (IgY) in Eggs of Broiler Breeders Fed Crude and Treated Vicia sativa Seeds
}

\author{
R. S. Mansour \\ Coll. of Vet. Med./Unive. of Mosul
}

\begin{abstract}
A trail of feeding broiler breeders crude and treated Vicia sativa at a rate of $11 \%$ and $22 \%$, was conducted to elucidate the effect of using this seed on the egg's IgY content and on the relative weight of the ovarian follicles. Results revealed that crude seeds were effective in significant reduction of $\mathrm{IgY}$ content and of the ovarian weight. Treating crude seeds at the low level (11\%) with water, acetic acid, Saccharomyces cereviceae and activated charcoal were effective in ameliorating the negative effects of antinutritional factors in crude $V$. sativa and transfer more immunoglobulin IgY through eggs comparing with control group. Treatment of crude seed at high level $(22 \%)$ were different in their effect on IgY content and the relative ovarian follicle weight. This study reveals and for the first time, that different treatments of crude $V$. sativa could enhance the maternal immunity transferred via IgY through eggs to off spring in order to improve the transferred maternal immunity to the hatched chicks and to sustain a high immunological profile against different infectious diseases.
\end{abstract}

Keywords: Immunoglobulin, IgY, Vicia sativa, broiler breeder.

\section{Introduction}

Legume crops such as vetch (Vicia sativa) and ervil (Vicia ervilia) are cultivated extensively in arid regions of central west Asia and north Africa as a high-protein forage for animals with increased grain yield and ability to sustain soil fertility (1). They are good source of protein and energy, containing about $25 \%$ crude protein and more than $3,100 \mathrm{Kcal}$ total metabolizable energy/Kg (2). They are used as an alternative source of protein in poultry diet (3). The presence of some antinutritional factors in the crude seeds limits their use in poultry diets (4).Vetch $V$. sativa contains vicine, convicine, and $\beta$ cyanoalanine, whereas ervil, $V$. ervilia contains in addition to those mentioned, canavanine (5). Crude vetch and ervil were reported to cause reduction in daily feed intake and egg production with an increase in feed conversion of fed layers $(6,3,2)$. Ervil was reported to decrease immune response of broiler to Newcastle disease vaccination (7).Three immunoglobulin classes which are distinguished in concentration, structure and immunochemical function, are found in birds: $\operatorname{IgA}, \operatorname{IgM}$ and $\operatorname{IgY}$. $\operatorname{IgY}$ is the major immunoglobulin class present in avian serum and egg yolk, and makes up about $75 \%$ of the total immunoglobulin pool $(8,9)$. In laying hens, circulating $\operatorname{IgY}$ is actively transferred into the yolk through the granulosa cell layer of developing follicle (10). This antibody gives immunity to the off springs (11). The aim of this study was to elucidate the effect of feeding crude and treated vetch on the content of egg IgY and relative ovarian follicles in broiler breeders.

\section{Materials and Methods}

treatments ( 6 females/ 1 male) (with two replicates), for each treatment.

Management: All birds were numbered by leg tags, and reared in 22 pens $(2 \mathrm{X} 3 \mathrm{~m})$, lined with wood shaving litter at depth of $5 \mathrm{~cm}$. Batteries with two raws and four openings were used. One hanged feeder and automatic waterer were used in each pen. Thermometers and hygrometers were
An experiment was carried out in the poultry farm at the college of agriculture and forestry, University of Mosul, for five months.

Birds: one hundred and thirty two female and 22 males (Ross/308) (23 weeks of age), were obtained from Erbil poultry company, and distributed randomly to 11 
T11; Ground V.S. seeds at rate of $22 \%$ amended with 500 ppm AC (ACVS2)

IgY Purification procedure: Eggs (10/treatment) were collected at the end of the experiment period (55 weeks). Yolk IgY was extracted and purified as described by (12) with minor modification, briefly as follows: eggs were individually broken and carefully put the egg sac on clean dry paper towel to discard the adhering egg white. Egg sac was punctured with the pasture pipette and egg yolk was collected. The yolks were diluted (1:9 $\mathrm{vol} / \mathrm{vol}$ ) with distilled water, $\mathrm{pH}$ 5.0-5.2 using HCL. After overnight storage at $4^{\circ} \mathrm{C}$, the samples were centrifuged at $3000 \mathrm{~g}$ for 30 minutes. The supernatant (water-soluble fraction) was collected then saturated ammonium sulfate was added. Precipitation was carried at room temperature, then samples were centrifuged, and the pellets were resuspended in PBS and dialyzed overnight.Two wave lengths were used to determine $\operatorname{IgY}$ egg content i.e. at $540 \mathrm{~nm}$ and $280 \mathrm{~nm}$. The first wave length was done by using Biuret test (13), while the second wave length was performed by the following way: duplicate 20-folds dilutions of the purified $\operatorname{IgY}$ in PBS (e.g., 50 $\mu$ l of purified $\operatorname{IgY}+950 \mu \mathrm{l}$ of $\mathrm{PBS})$ were prepared. IgY concentration $(\mathrm{mg} / \mathrm{ml})$ was calculated using the following relationship: A280 divided by 1.4 equals concentration in $\mathrm{mg} / \mathrm{ml}$ multiply by 20 to obtain the concentration of the undiluted IgY sample (14).

Statistical analysis: The significancy in the concentration of yolk IgY and the relative weight of ovary were determined by oneway ANOVA followed by Duncan's multiple-range test using SPSS program (version 11) (15). distributed in three points of the house for recording temperature and humidity. Automatic ventilators were established to sustain $70 \%$ relative humidity and temperature not more than $26^{\circ} \mathrm{C}$. lighting program was $16 \mathrm{hL} / 8 \mathrm{hD}$.

Feeding: Broilers breeders (male and females) were fed a diet contained 2750 $\mathrm{Kcal} / \mathrm{Kg}$ feed and $16 \%$ crude protein. Each bird was offered with 160-165 g/day. Water was given ad libidum.

Vaccination: All birds were obtained after their vaccination by the program recommended by the Erbil poultry company.

Treatments: Broiler breeders were randomly distributed into the following groups:

T1; Control (C)

T2; Ground V. sativa (VS) seeds at a rate of $11 \%$ (VS1)

T3; Ground V.S. seeds a rate of $11 \%$ soaked in water at $40{ }^{\circ} \mathrm{C}$ for $24 \mathrm{~h}$, then autoclaved (WSAVS1)

T4; Ground V.S. seeds at a rate of $11 \%$ soaked in acetic acid $(4 \%)$ at $40^{\circ} \mathrm{C}$ for $24 \mathrm{~h}$, then autoclaved (ASAVS1)

T5; Ground V.S. seeds at a rate of $11 \%$ amended with $2 \%$ Saccharomyces cereviceae (SC) (SCVS1)

T6; Ground V.S. seeds, at a rate of $11 \%$ amended with 500 ppm activated charcoal (AC) (ACVS1)

T7; Ground V.S. seeds at a rate of $22 \%$ (VS2)

T8; Ground V.S. seeds at a rate of $22 \%$ soaked in water at $40^{\circ} \mathrm{C}$ for $24 \mathrm{~h}$ then autoclaved (WSAVS2)

T9; Ground V.S. seeds at a rate of $22 \%$ soaked in acetic acid $(4 \%)$ at $40^{\circ} \mathrm{C}$ for $24 \mathrm{~h}$ the autoclaved (ASAVS2)

T10; Ground V.S. seeds at a rate of $22 \%$ amended with $2 \%$ SC (SCVS2)

\section{IgY concentration:}

The effect of feeding crude and treated $V$. sativa at a rate $11 \%$ and $22 \%$ to broiler breeders on egg IgY concentration is illustrated in table 1 and 2, which revealed that feeding low level of $V$. sativa seeds (11\%) in a crude form was not harmful to the concentration of broiler

\section{Results}

breeder egg IgY, and so all the treated groups (WSAVS1, ASAVS1, SCVS1 and ACVS1). There were no significant differences between these groups when compared with control group. Increasing crude $V$. sativa seeds to $22 \%$ was responsible for a significant reduction $(\mathrm{P}<0.05)$ in egg IgY of broiler breeders. 
Treatments of crude seeds at this level was effective in restoring IgY level to that of the control one only in the groups
(ASAVS2, SCVS2 and ACVS2), but without beneficial effect in (WSAVS2) when these seeds were soaked in water.

Table 1: IgY concentration at $(280 \mathrm{~nm})$ in eggs of broiler breeders fed crude and treated $V$. sativa at 55 weeks of age.

\begin{tabular}{|c|c|c|}
\hline Groups & Treatment & IgY $(\mathrm{mg} / \mathrm{ml})$ \\
\hline 1 & T1 & $* 3.913 \pm 0.282 \mathrm{~d}^{* *}$ \\
\hline 2 & T2 & $3.142 \pm 0.252 \mathrm{~cd}$ \\
\hline 3 & T3 & $3.516 \pm 0.295 \mathrm{~cd}$ \\
\hline 4 & T4 & $3.673 \pm 0.555 \mathrm{~cd}$ \\
\hline 5 & T5 & $3.513 \pm 0.223 \mathrm{~cd}$ \\
\hline 6 & T6 & $3.873 \pm 0.325 \mathrm{~cd}$ \\
\hline 7 & T7 & $1.880 \pm 0.409 \mathrm{a}$ \\
\hline 8 & T8 & $2.277 \pm 0.107 \mathrm{ab}$ \\
\hline 9 & T9 & $3.177 \pm 0.054 \mathrm{~cd}$ \\
\hline 10 & T10 & $3.266 \pm 0.141 \mathrm{~cd}$ \\
\hline 11 & T11 & $3.384 \pm 0.168 \mathrm{~cd}$ \\
\hline
\end{tabular}

$*=$ Mean \pm S.E. of $10 \mathrm{egg} /$ treatment

$* *=$ The different letters in different treatments mean significant differences at level of $(0.05)$

Table 2: concentration of $\operatorname{IgY}$ at $(540 \mathrm{~nm})$ in egg of broiler breeders fed crude and treated $V$. sativa at 55 weeks of age.

\begin{tabular}{|c|c|c|}
\hline Groups & Treatment & $\operatorname{IgY}(\mathrm{mg} / \mathrm{dl})$ \\
\hline 1 & T1 & $* 0.264 \pm 0.013 \mathrm{bc}^{* *}$ \\
\hline 2 & T2 & $0.220 \pm 0.026 \mathrm{~b}$ \\
\hline 3 & T3 & $0.233 \pm 0.025 \mathrm{bc}$ \\
\hline 4 & T4 & $0.262 \pm 0.028 \mathrm{bc}$ \\
\hline 5 & T5 & $0.257 \pm 0.029 \mathrm{bc}$ \\
\hline 6 & T6 & $0.283 \pm 0.022 \mathrm{bc}$ \\
\hline 7 & T7 & $0.129 \pm 0.026 \mathrm{a}$ \\
\hline 8 & T8 & $0.131 \pm 0.014 \mathrm{a}$ \\
\hline 9 & T9 & $0.285 \pm 0.034 \mathrm{bc}$ \\
\hline 10 & T10 & $0.265 \pm 0.304 \mathrm{bc}$ \\
\hline 11 & T11 \\
\hline
\end{tabular}

$*=$ Mean \pm S.E. of $10 \mathrm{egg} /$ treatment

$* *=$ The different letters in different treatments mean significant differences at level of $(0.05)$

Ovarian relative weight
The effect of feeding crude and treated $V$. sativa on ovarian relative weight is represented in table 3: 
Table 3: Effect of feeding crude and treated $V$. sativa on ovarian relative weight $(\mathrm{g} / 100 \mathrm{~g}$ body weight) in broiler breeders at 55 days of age.

\begin{tabular}{|c|c|c|}
\hline Groups & Treatment & $\begin{array}{c}\text { Ovarian relative weight } \\
(\mathrm{g} / 100 \mathrm{~g} \text { B.W. }\end{array}$ \\
\hline 1 & $\mathrm{~T} 1$ & $* 14.60 \pm 0.784 \mathrm{a}^{* *}$ \\
\hline 2 & $\mathrm{~T} 2$ & $11.60 \pm 1.208 \mathrm{~b}$ \\
\hline 3 & $\mathrm{~T} 3$ & $12.76 \pm 0.912 \mathrm{ab}$ \\
\hline 4 & $\mathrm{~T} 4$ & $12.96 \pm 1.395 \mathrm{ab}$ \\
\hline 5 & $\mathrm{~T} 5$ & $12.76 \pm 1.095 \mathrm{ab}$ \\
\hline 6 & $\mathrm{~T} 6$ & $13.10 \pm 0.940 \mathrm{a}$ \\
\hline 7 & $\mathrm{~T} 7$ & $10.66 \pm 1.093 \mathrm{~b}$ \\
\hline 8 & $\mathrm{~T} 8$ & $11.70 \pm 1.445 \mathrm{~b}$ \\
\hline 9 & $\mathrm{~T} 9$ & $12.70 \pm 1.178 \mathrm{ab}$ \\
\hline 10 & $\mathrm{~T} 10$ & $11.70 \pm 0.969 \mathrm{~b}$ \\
\hline 11 & T11 & $11.70 \pm 1.496 \mathrm{~b}$ \\
\hline
\end{tabular}

$*=$ Mean \pm S.E. of $10 \mathrm{egg} /$ treatment

$* *=$ The different letters in different treatments mean significant differences at level of $(0.05)$

From the table (3) it is evident that both crude $V$. sativa at $11 \%$ and $22 \%$ were responsible for significant $(\mathrm{P}<0.05)$ reduction in ovarian relative weight. All treatments of $11 \%$ were effective in restoring ovarian follicle relative weight to

\section{Discusion}

A huge challenges all the times and all over the world facing poultry industry, due to microbiological and chemical hazards. The highly demand of poultry products (meat and eggs) urge us to sustain high standard of immunity in different poultry flocks and their fertilized egg to overcome the stress in the period after hatching.So yolk $\operatorname{IgY}$ is important as antibodies that help to protect the embryo and the chicks from pathogens in a period before its immune capabilities are fully matured (16), and these antibodies are transferred from hen to chick via eggs, and play an important role in chicks to resist various infectious diseases (9). Although, many authors studied the concentration of IgY in eggs under different feeding and environmental conditions, but no available studies at our knowledge were referred to its concentration through feeding antinutritional factors of $V$. sativa, hence in our study the mean concentration of $\operatorname{IgY}$ in control group was $(3.913 \pm 0.282)$ at 280 $\mathrm{nm}$ and $(0.264 \pm 0.013)$ at $540 \mathrm{~nm}$ (table 1 the weight of control one, with best results in using activated charcoal, while the treatment of $22 \% \quad \mathrm{~V}$. sativa was only effective through treatment with acid, which give results close to that of control one.

and 2), which is lower than that reported by (17), who found that its concentration was $(6.19 \pm 0.44)$ in Dekalb laying hens, and $(5.73 \pm 0.64)$ in Nagoya laying hens, and (12.2 \pm 2.04$)$ in PNP/DO laying hens. These variations in IgY content in our study and other studies could be due to the differences in strains of chickens (18) or by the methods of preparing IgY yolk extract which differed among investigators (17). The most probable explanation for depletion of $\mathrm{IgY}$ in birds fed crude $V$. sativa seeds is that these seeds require sulfur donors for the detoxification of its cyanide content to thiocyanates $\left(\mathrm{SCN}^{-}\right)$, in which sulfane sulfur playing a critical role. Sulfane sulfur appears to be formed from cystine via transamination and subsequent reactions catalyzed by Rhodanese and 3mercaptopyruvate sulfurtransferase (19). Cystine, however is also a vital aminoacid involved in the structure and function of immunoglobulins (20). So, through the process of cyanide detoxification, sulfane pole may be subjected to depletion 
process, this depletion process may impair all the normal functions of this pool, including providing sulfur for the disulfide bound bridge of IgM, IgG (hen IgY) and IgA (21).This effect was also reported by (22) who found that Cassava (a cyanogenic glycoside), could adversely influence the levels and possibly the function of serum immunoglobulins in Liberian citizens consumed this vetch. Since, he found that among the three immunoglobulins (IgA, $\operatorname{IgM}$ and $\mathrm{IgG}$ ), $\operatorname{IgG}$ was reported to be in low level in females of Liberian people fed low, moderate or high levels of dietary cyanide. A related results were observed by (7), who found that the immune response to Newcastle disease virus in broiler fed $V$. ervilia seeds at a rate of $25 \%$ was also responsible for immunosuppression with regard to antibody titers to NDV vaccination. At the cellular level, cyanide could affect the formation of granulosa cells layer of ovarian follicles during follicular development, especially in layers fed the higher level of $V$. sativa seeds in their crude form, since, these cells are considered as a fundamental part in the actively transferring of circulating immunoglobulin Y into the yolk (23). The low ovarian weight in our experiment especially in birds fed high level (22\%) of crude $V$. sativa seeds table (3), could also explain the significant reduction of $\operatorname{IgY}$ in this group. Since, IgY content in eggs is proportionally related to the reproductive ability of hens because estrogen injection increases significantly $\operatorname{IgY}$ concentration in yolk and in IgY containing cell (24) So, cessation of egg production caused by feeding crude $V$. sativa (2), means the

\section{Acknowledgements}

The author is so grateful to the College of Agriculture and Forestry, University of Mosul for their assistance in reduction of ovarian ability and to the observed reduction in IgY concentration. All the treatments used with low $V$. sativa seeds level $(11 \%)$ as well as the treatments with the higher level $(22 \%)$ except (that with water soaking) were effective in freeing the antinutritional or toxic factors in crude $V$. sativa, through disintegrating and removing of these toxins, by using water or acetic acid soaking (2), or by sequestering these factors using $S$. cereviceae or the activated charcoal (25) However, as to our knowledge, none of the previous studies investigated a direct or indirect effect of $V$. sativa antinutritional factors, nor the methods of their detoxification on IgY level in broiler breeder eggs. The study of (7), was effective in amelioration of $V$. ervilia (a cyanogenic glycoside) on the titer of NDV using water and acid soaking, but no previous work was dealing with the direct $S$. cereviceae or activated charcoal on immunological status of laying birds. It should be stressed that cyanide should be estimated in different types of poultry rations in order to elucidate their negative effect on the immune system and thereafter to take suitable action to counteract this undetected hidden enemy.In conclusion, it could be said that the quantitative determination of the immune response to IgY in broiler breeders could be used as a model in the assessment of different detoxification treatments of crude $V$. sativa seeds in poultry feeding, in order to improve the transferred maternal immunity to the newly hatched chicks and to sustain the immunological profile against different infectious diseases.

\section{References}

1- ICARDA. (2004). Pages 30-32 in ICARDA annual report 2003. International center for Agriculture Research in the dry Areas, Alepp, Syria. accomplishing this research and also so thankful for the various forms of assistance.
2- Farran, M.T., Barbour, G.W., Uwayjan, M.G. and Ashkariam, V.M. (2001). Metabolizable energy values and amino acid availability of vetch (Vicia 
sativa) and ervil (Vicia ervilia) seeds soaked in water and acetic acid. Poultry sci. 80:931-936.

3- Farran, M.T. Dakessian, P.B., Uwayjan, M.G., Sleiman, F.T. and Ashkarian, V.M. (1998). Performance of broilers and layers fed high levels of treated vetch (Vicia sativa) seeds. Poultry Sci. 77(suppl.1): 48. (Abstr.)

4- Cheeke. P.R., and Shull, L.R. (1985). Natural toxicants in feeds and poisonous plants. AVI Publishing Company, Inc., West-port, CT.

5- Angeles, G.M., and Ferrando, L (1992). Colorimetric estimation of canavanine in Vicia evilia alone or mixed with other legumes. Nutr. Abstr. Rev. (series B) 62(1):12.(Abstr.)

6- Farran, M.T., Uwayjan, M.G., Miski, A.M.A., Sleiman, F.T., Adada, F.A., and Ashkarian, V.M. (1995). Effect of feeding raw and treated common Vetch seed (Vicia sativa) on the performance and egg quality parameters of laying hens. Poult. Sci. 74:16301635.

7- Barbour, EK, Kallas M, Farran MT.(2001). Immune response to Newcastle disease virus in broilers: a useful model for the assessment of detoxification of ervil seeds. Rev. Sci.tech. off. Int. Epiz.; 20(3): 785-790.

8- Leslie, G.A., and Martin, L.N (1973). Studies on the secretory immunologic system of fowl.3. serum and secretory $\operatorname{IgA}$ of the chicken. J. Immunol., 110(1), 19.

9- Chalghoumi, R., Beckers, Y., Portetelle, D., Thewis, A. (2009). Hen egg yolk antibodies (IgY), production and use for passive immunization against bacterial enteric infections in chicken: a review. Biotechnol. Agron. Soc. Environ. 13(2), 295-308.
10- Higgins, D.A. (1996). Comparative immunology of avian species. In: Poultry Immunology (Davison, T.A., Morris, T.R., and Payne, L.N. eds.) Carfax publishing Co. Oxfordshire, pp. 149-205.

11- Klemperer, F. (1893). Ueber natülich immunität und verwerthung für die immunisirungsthrapie Arch. Exp. Pathol. Pharmacol. 31:356382.(cited by: Chalghoumi, R., Beckers, Y., Portetelle, D., Thewis, A. (2009). Hen egg yolk antibodies (IgY), production and use for passive immunization against bacterial enteric infections in chicken: a review. Biotechnol. Agron. Soc. Environ. 13(2), 295-308).

12- Akita E.M. and Nakai S. (1992). Immunoglobulins from egg yolk: isolation and purification. J. of food science, 57: 639-634.

13- Tietz, N.W.(1982). Fundamentals of Clinical Chemistry. $2^{\text {nd }}$ ed. W.B. Saunders Company.pp302304.

14- Anonymous. (2008). www.therrmo.com/pierce. Instructions, pierce ${ }^{\circledR}$ Chicken IgY purification kit.

15- SPSS 10 for windows computer software. (1999). SPSS. Inc., 233 South wacker drive, $11^{\text {th }}$ floor, Chicago 11. USA.

16- Dohms, J.E., Saif, Y.M. and Bacon, W.L. (1978). Metabolism and passive transfer of immunoglobulins in the turkry hen. American J.Vet. Resc. 39: 1472-1480.

17- Kitaguchi, K, Minoura, M., Noritake, M., Mizutani, M., Kinoshita, K., Horio, F., Murai, A.(2008). Determination of immunoglobulin $\mathrm{Y}$ concentration in yolk extract prepared by water dilution method: Comparisons among three strains of chickens. J poult. Sci., 45;82-87. 
18- Gross, WB and Siegel, PB.(1990). Genetic-environmental interactions and antibody response in chickens to two antigens. Avian Diseases.34:843847.

19- Vennesland B, Castric PA, Conn EC.(1982). Cyanide metabolism. Fed Proc. 91:2639-2648.

20- Milsten C. Chemical structure of light chains. Proc R SOC land. (1966); 166:138-146.

21- Westley J.(1981). Cyanide and Sulfane sulfur in: Vennes land B; Conn EE, Knowles CJ, Westley $\mathrm{J}$, and Wissing F. eds. Cyanide in biology. London: Academic Press. pp 61-76.

22- Jackson, LC, Bloch EF., Jackson RT, Chandler, JP., Kim, YL., Malveaux FJ. (1985). Influence of dietary cyanide on immunoglobulin and thiocyanade levels in the serum of Liberian adults. Journal of the national medical association. 77(10):777782.

23- Rose, M.E.M., and Orlans, E. (1981). Immunoglobulins in the egg, embryo and young chick. Developmental and comparative Immunology, 5:15-20

24- Barua, A, Furusawa, S., and Yoshimura, Y.(2000). Influence of aging and estrogen treatment on the IgY concentration in the egg yolk of chicken, Gallus domasticus. Japanese poultry science. 37: 280-288.

25- Lambert, R. J., Kindler, B. L., Schaeffer, D.J. (1988). The effecting of superactivated charcoal in treating rats exposed to a lethal oral dose of potassium cyanide. Annals of Emergency Medicine; 17(6): 595-598.

\section{الكشف عن الكلوبيولين المناعي IgY في بيض أمهات فروج اللحم المستهلكة لبذور البيقيا الخام والمعاملة البيات}

$$
\text { كلية الطب البيطري/ سالم منصورة المولة الخوصل }
$$

تهدف الدر اسة لمعرفة تأثثر معاملة بذور البيقيا الخام بنسبة 11\% و22\% المستخدمة في تغذية أمهات فروج

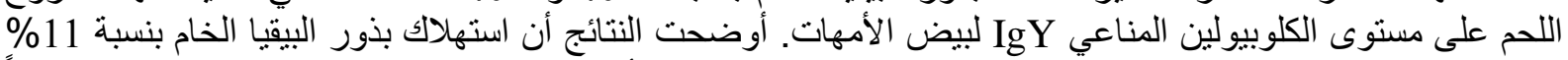

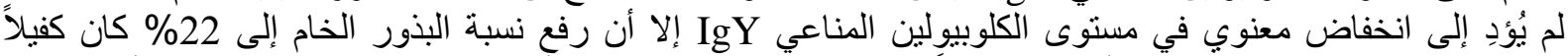

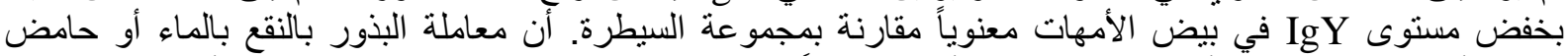
الخليك أو بإضافة الخميرة أو الفحم المنشط قد أظهر تحسناً في مستوى IgY في المعاملات في بيض الأمهات المستهلكة لبذور البيقيا الخام بنسبة 22\% و أوصلت المعاملات بالحامض أو بإضافة الخميرة والفحم المنشط مستوى IgY لقيم مقاربة لما هي عليه في مجموعة السيطرة عدا المجموعة المعاملة بالماء. كما وأثز استهالاك بذورة البية اليقيا الخام بنسبة

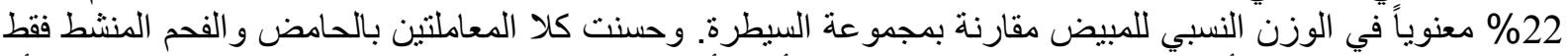

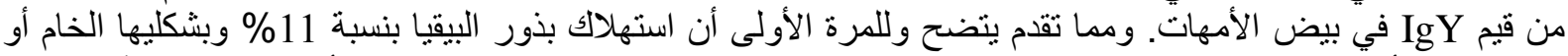
المعامل في أمهات فروج اللحم لا يؤثر في مستوى IgY وانتقاله عن طريق البيض إلى الألى الأفراخ الفاقسة ويُيقي على الإنى

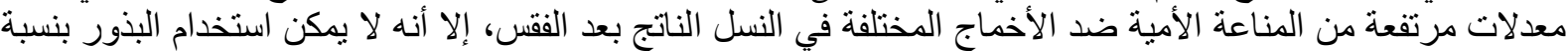

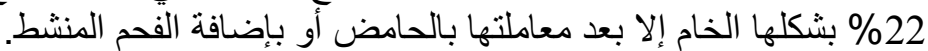

